\title{
Experimental model of traumatic ulcer in the cheek mucosa of rats ${ }^{1}$
}

\author{
Modelo experimental de úlcera traumática em mucosa jugal de ratos
}

\author{
Galyléia Meneses Cavalcante', Renata Janaína Sousa de Paula', Leonardo Peres de Souza", Fabrício Bitu Sousa ${ }^{\mathrm{III}}$, Mário Rogério

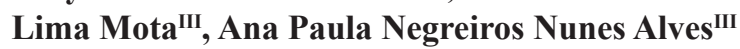 \\ ${ }^{1}$ Research performed at Laboratory of Oral Pathology, Dental Clinic College, Federal University of Ceara (UFC), Brazil. \\ ${ }^{\mathrm{I}}$ Graduate Student, Odontology, UFC, Ceara, Brazil. Acquisition, interpretation of data and manuscript writing.

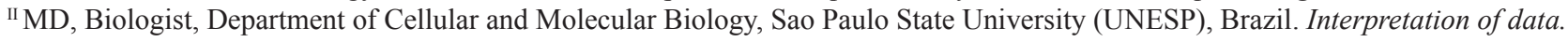 \\ III Associate Professor, Clinical Odontology, Pharmacy, Odontology and Nursing College, UFC, Brazil. Conception, design, responsible for intellectual, \\ scientific content of the study and critical revision.
}

\begin{abstract}
Purpose: To establish an experimental model of traumatic ulcer in rat cheek mucosa for utilization in future alternative therapy studies. Methods: A total of 60 adult male rats $(250-300 \mathrm{~g})$ were used. Ulceration of the left cheek mucosa was provoked by abrasion using a $\mathrm{n}^{\mathrm{o}} 15$ scalpel blade. The animals were observed for 10 days, during which they were weighed and their ulcers were measured. The histological characteristics were analyzed and scored according to the ulcer phase. In the statistical analysis, a value of $\mathrm{p}<0.01$ was considered a statistically significant response in all cases. Results: During the five first days, the animals lost weight (Student $t$ test, $\mathrm{p}<0.01$ ). The ulcerated area receded linearly over time and was almost completely cicatrized after 10 days (ANOVA, Tendency posttest, $\mathrm{p}<0.0001$ ). Groups on days 1, 2 and 3 days displayed similar results, but a decrease in scores were observed after the 4th day. Conclusion: The proposed cheek mucosa ulcer model in rats can be considered an efficient, low-cost, reliable, and reproducible method. Key words: Ulcer. Mouth Mucosa. Wound Heling. Rats.
\end{abstract}

\section{RESUMO}

Objetivo: Estabelecer um modelo experimental de úlcera traumática em mucosa jugal de ratos para utilização em futuros testes de terapias alternativas. Métodos: Foram utilizados 60 ratos, adultos, machos, pesando entre 250 a $300 \mathrm{~g}$. A ulceração na mucosa jugal esquerda foi provocada por meio da abrasão desta com uma lâmina de bisturi número 15. Os animais foram observados por um período de 10 dias, sendo estes pesados e suas escoriações mensuradas. As características histológicas foram analisadas e descritas adotando escores para comparação dos estágios da fase da úlcera. Na análise estatística um valor de p<0,01 foi considerado uma resposta estatisticamente significante em todos os casos. Resultados: Durante os cinco primeiros dias os animais perderam peso (" $t$ " Student - $\mathrm{p}<0,01)$. A área da úlcera regrediu linearmente com o tempo, estando quase que completamente cicatrizada ao final de dez dias (ANOVA, pós-teste de Tendência - p<0,0001). Os grupos do $1^{\circ}, 2^{\circ}$ e $3^{\circ}$ dias tiveram comportamento semelhante havendo uma diminuição dos escores a partir do $4^{\circ}$ dia. Conclusão: O modelo de úlcera na mucosa jugal de ratos proposto pode ser considerado eficaz, apresentando reprodutibilidade confiável e baixo custo.

Descritores: Úlcera. Mucosa Bucal. Cicatrização de Feridas. Ratos. 


\section{Introduction}

Traumatic ulcers in the oral cavity are relatively frequent and are usually a result of mechanical injuries. Traumatic ulcers are usually found in non-keratinized surfaces such as the cheek mucosa, edge of the tongue, lips, gingiva and hard and soft palates $^{1-3}$. Lesions in the gums and cheek mucosa can be caused by other forms of irritation such as brushing, which causes linear erosion along the free gingival margin and is sometimes related to areas of hyperkeratosis ${ }^{3}$. These ulcers are usually ovoid and painful, being limited to the area subjected to the damage. They can present as a white-yellowish necrotic center surrounded by a wide erythematous band ${ }^{3-5}$. They generally measure around $1 \mathrm{~cm}$ and evolve to spontaneous healing in a period that can vary from 10 to 14 days, without leaving a scar ${ }^{4,6,7}$.

It is also known that ulcers are common manifestations in a spectrum of conditions that vary from auto-immune diseases to malign neoplasias and infectious processes, nutritional deficiencies, allergic reactions, traumatisms and iatrogenic factors. The evolution of the clinical profile of an ulcer can be classified into 4 stages of development: the first is represented by a symptomatic aspect, characterized by pruriginous sensation, pain and mucosal roughness in the first 24 hours. The second stage is pre-ulcerative and shows erythema, localized macula with discreet elevation and hard consistency, presenting with a superficial circular membrane, erythematous halo and pain. The third is the ulcerative stage when the membrane is whitish and necrotic, which happens during the period from days 1 to 3 . A whitish-yellow fibrinous exudate is formed on the ulcer floor; then the erythematous halo persists, and the lesion assumes a crateriform aspect. In this stage, the ulcer reaches its developmental peak, and the pain recedes, becoming merely a sensation of discomfort. The repair stage happens spontaneously ${ }^{8}$.

From the microscopic point of view, the mucosa that covers the mouth is represented by an external layer of epithelial cells that is supported by connective tissue of variable constitution. This mucosa is a protective barrier for the organism because it does not allow for penetration of any external agent that can be harmful to health ${ }^{9}$. The ulcerations present discontinuity of the epithelial surface and are covered by a fibrinopurulent membrane mixed with neutrophils. Granulation tissue can be observed at the base of the ulcer, which supports an inflammatory infiltrate-a mixture of lymphocytes, histiocytes, neutrophils and occasionally plasmocytes ${ }^{10}$. The constitution of this infiltrate will vary according to the evolution phase of the ulcer. In the initial phases after the injury, neutrophils predominate, performing phagocytosis. After undergoing apoptosis, the neutrophils are progressively substituted by monocytes. In addition, chemotaxic factors for neutrophils and monocytes are activated during the different periods of inflammation, maintaining the migration of monocytes after the migration of neutrophils has ceased. Approximately 3 days after the histological profile of the ulcer starts to present alterations, the cellular infiltration becomes predominantly lymphoplasmacytic, which is characteristic of chronic inflammation. It is in this phase that the proliferation of blood vessels and fibroblasts occurs, signaling the beginning of repair. Although neutrophils are characteristic of acute inflammation, they can also be found in sites of chronic inflammation of long durations, such as in the case of a bacterial infection or necrotic tissue, and they can also persist if they are continually recruited by chemotactic agents ${ }^{19}$.

Despite the variety of topical agents, antibiotics, local anesthetics, antihistamines, non-steroidal anti-inflammatory agents and enzymatic preparations used for symptom relief, there is no consensus on the efficacy of medications that are currently available because many of these agents have not been properly evaluated and have only been used empirically. Thus, the objective of this study was to establish an experimental traumatic ulcer model that could be used in future alternative therapy studies.

\section{Methods}

The Ethical Principles of Animal Experimentation of the Brazilian College of Animal Experimentation (COBEA, institution associated with the International Council for Laboratory Animal Science and Brazilian Legislation on Experimental Animals (Federal Law nº 6.638 (1979) were adopted.

The research project was submitted and approved by the Ethics Committee of Animal Research (CEPA) of UFC, protocol $\mathrm{n}^{\mathrm{o}} .82 / 08$.

A total of 60 rats were studied (Rattus norvegicus albinus, Rodentia mammalia) that were all: Wistar lineage adult males aged between $2-3$ months and weighing between 250 and $300 \mathrm{~g}$. The rats were acquired from the Central Animal Colony of UFC.

The rats were kept in plastic cages with pine-sawdust covered floors at a temperature of $24^{\circ} \mathrm{C}$ in a dark-light cycle of 12 hours with free access to water and commercial food (Bio-base).

The animals were randomly distributed into 10 cages with 6 animals each, identified and weighed daily. The date of sacrifice was recorded for each rat. 


\section{Experimental protocol}

The animals were anesthetized with $10 \%$ chloral hydrate $(30 \mathrm{ml} / 0.1 \mathrm{~g})$ via intraperitoneal injection, and the surgical process was initiated the eyelid reflex and a constant breathing rhythm ceased. The animals were observed during the post-operatory period until the total recovery of reflexes.

After the anesthetic stage was reached, each animal was put on a surgical table in dorsal decubitus and immobilized with adhesive tape. The mucosa was sterilized by using a swab covered in $0.12 \%$ chlorhexidine digluconate.

The ulceration was made on the left cheek mucosa by abrasion using a $\mathrm{n}^{\mathrm{o}} 15$ scalpel blade. To standardize the lesion area, an 8-mm-diameter demarcator was used. The operation technique was standardized for all the animals and was performed by the same examiner. The ulceration was not performed in the control group, in which the animals were anesthetized, and the variation of body weight was observed.

The animals were observed daily for 10 days. They were weighed and their ulcers were measured with a $0.5-\mathrm{mm}$ precision digital paquimeter $(\mathrm{D}=$ biggest diameter and $\mathrm{d}=$ smaller diameter $)$ to calculate the area $(A=\pi . r . R)^{11}$. The animals were gradually sacrificed: each group was sacrificed in intervals of 24 hours through the end of the 10-day study period. After the animals were sacrificed, a section of the cheek mucosa containing the induced ulcer was collected.

\section{Histopathological analysis}

The collected cheek mucosa fragments were identified and immersed in 10\% formol for 24 hours. After fixation in formol, the specimens were macroscopically analyzed, subjected to dehydration in crescent alcoholic series, diaphanized in xylol, impregnated in paraffin and melted at $60 \%$. Then, the fragments were put into paraffin-forming blocks at room temperature. The fragments were sectioned to $5 \mu \mathrm{m}$ in thickness through the use of a microtome and histology using routine coloration by eosinhematoxylin was performed. Analysis was performed with an optical microscope from the Oral-dental Pathology Laboratory of the Odontological Clinic Department of UFC, and the histological characteristics of the ulcer along with their corresponding cicatrization phases were described.

The histopathological parameters were determined and scored from 0 to 4 according to the information below (adapted from Cho et al. ${ }^{12}$ ):
0 . No ulcer / remodeled connective tissue

1. No ulcer / fibrosis + slight chronic inflammation

2. With ulcer / fibrosis + moderate chronic inflammation

3. With ulcer / chronic inflammation process (granulation tissue)

4. With ulcer / acute process (dilated vessels, mixed inflammatory infiltrate with neutrophilis)

\section{Statistical analysis}

All data were analyzed using GraphPad Prism 5.0 (demo version). Student's $t$ test was performed to verify the difference between the averages of the weights obtained before and after ulceration in each group. The comparison test of the ulcerated areas among groups was analyzed using ANOVA followed by the Tendency post-test. The histological scores were compared by Kruskal-Wallis non-parametric test followed by the Dunn post-test. Data of the ulcer area and time were adjusted to a doseresponse model to determine the time at which the ulcers were $50 \%$ cicatrized. A value of $\mathrm{p}<0.01$ was considered a statistically significant response in all cases.

\section{Results}

\section{Macroscopic evaluation of injuries}

During the first 4 days, the injuries in the cheek mucosa of the animals were clinically visible and were crateriform, bleeding and red (Figure 1).

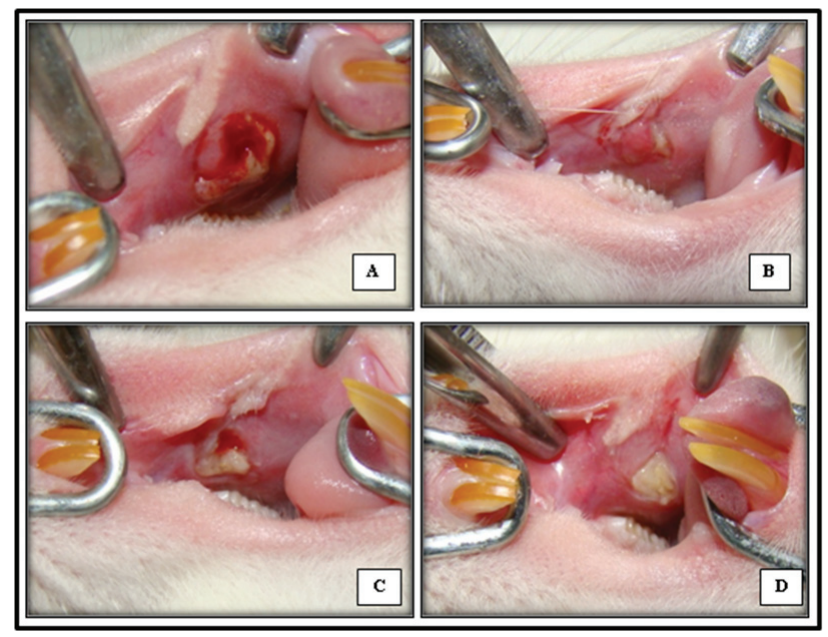

FIGURE 1 - Clinical aspects of the traumatic ulcers in the left cheek mucosa within one (A), two (B), three (C) and four days (D) after the induction of the trauma with an $\mathrm{n}^{\circ} 15$ scalpel blade. 
From days 5 to 8 , the size of the injuries decreased; however, some of them were not totally cicatrized and still had irregular borders and the presence of a whitish halo surrounding the reminiscent injury (Figure 2).

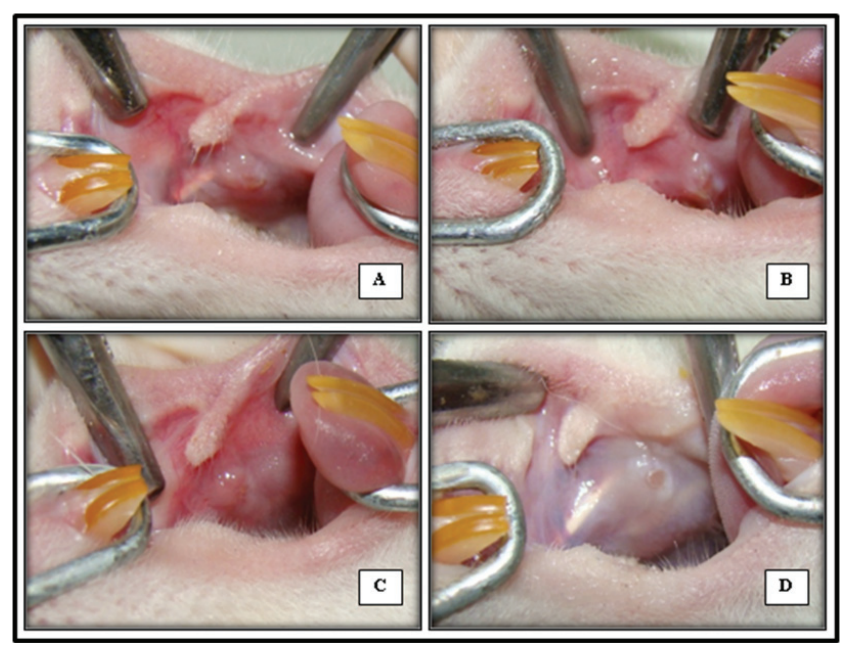

FIGURE 2 - Clinical aspect of the traumatic ulcers in the left cheek mucosa five (A), six (B), seven (C) and eight days (D) after the induction of the trauma with a $\mathrm{n}^{\mathrm{o}} 15$ scalpel blade.

On the ninth and tenth days, the cheek mucosa of the animals where the ulceration was induced was cicatrized, uniform and presented regular borders (Figure 3).

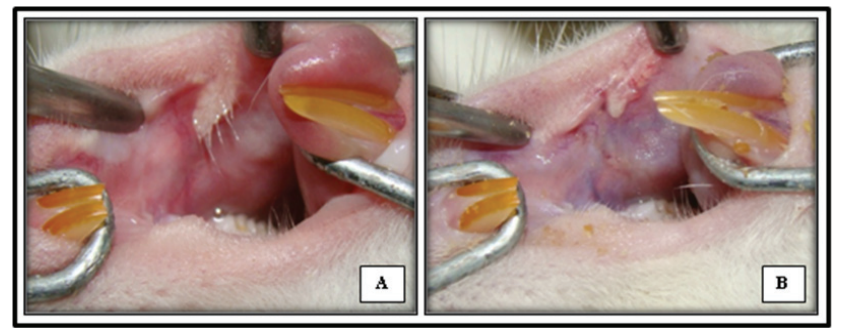

FIGURE 3 - Clinical aspect of the traumatic ulcers in the left cheek mucosa nine (A) and ten days (B) after the induction of the trauma with a ${ }^{\circ} 15$ scalpel blade.

\section{Body weight and ulcerated area analysis}

The surgical procedures were satisfactory, and all the animals remained alive during the operation without any preoperatory or anesthetic complications.

Concerning the weight (Figure 4), a progressive reduction was observed in the animals subjected to ulceration until the fifth day, which was statistically significant compared to the weight initial the procedure. From this day on, the animals started to gain weight; however, it was more evident from the tenth day when it became statistically significant $(\mathrm{p}<0.01)$. In regards to the control group, no significant difference was observed between the final and initial weights $(\mathrm{p}>0.01)$.

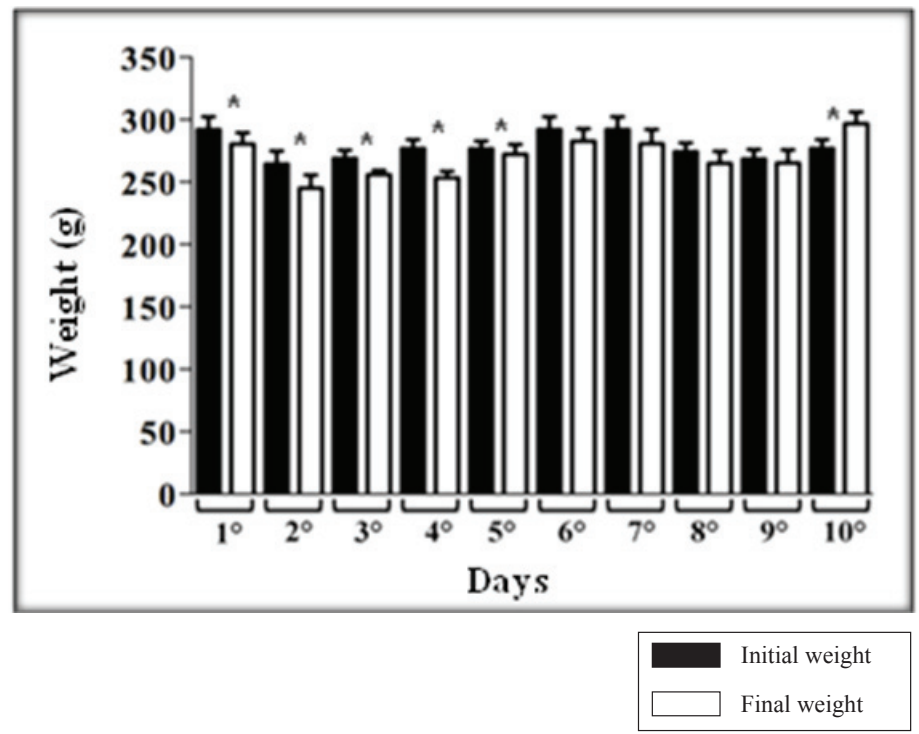

FIGURE 4 - Daily variation of the body weight of the animals subjected to the process of traumatic ulcer induction in the cheek mucosa over the 10 -day period. The data are presented as mean \pm SEM The statistical analysis was performed using Student's t-test with $p<0.01{ }^{*}$ Data with statistical significance on the 1st, $2 \mathrm{nd}, 3 \mathrm{rd}, 4 \mathrm{th}, 5$ th and 10th day.

For the analysis of the ulcerated area (Figure 5A), a tendency for linear regression with time was observed, and the injury in the cheek mucosa of the animals was almost completely cicatrized by the end of the 10-day period. Concerning the contraction behavior of the ulcer in relation to time (Figure 5B), the adjustment of the dose-response curve showed that $50 \%$ of the ulcerated area was contracted in about 4.5 days or 108 hours after ulcer induction. 

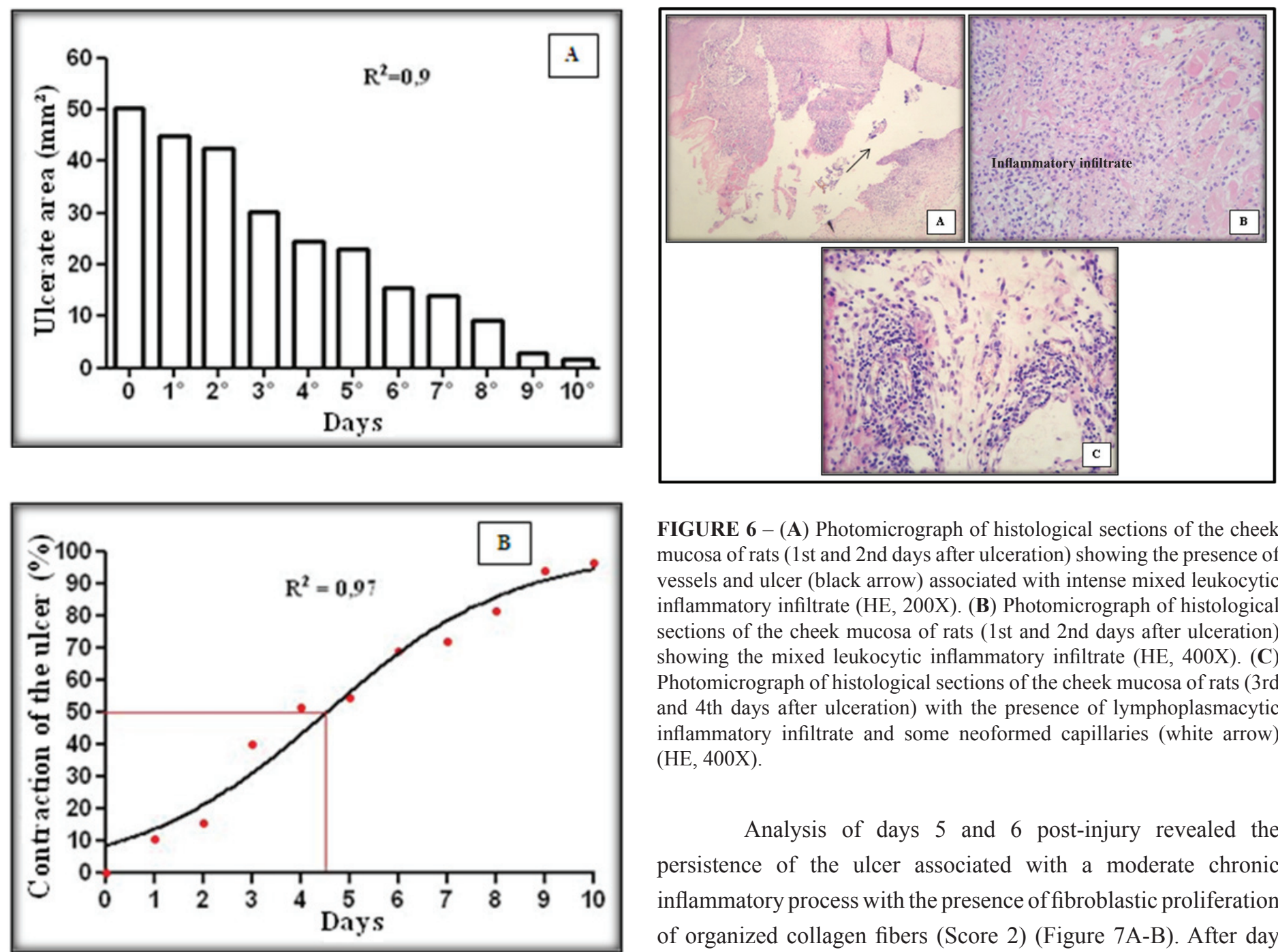

FIGURE 6 - (A) Photomicrograph of histological sections of the cheek mucosa of rats (1st and 2nd days after ulceration) showing the presence of vessels and ulcer (black arrow) associated with intense mixed leukocytic inflammatory infiltrate (HE, 200X). (B) Photomicrograph of histological sections of the cheek mucosa of rats (1st and 2nd days after ulceration) showing the mixed leukocytic inflammatory infiltrate (HE, 400X). (C) Photomicrograph of histological sections of the cheek mucosa of rats (3rd and 4th days after ulceration) with the presence of lymphoplasmacytic inflammatory infiltrate and some neoformed capillaries (white arrow) (HE, 400X).

Analysis of days 5 and 6 post-injury revealed the persistence of the ulcer associated with a moderate chronic inflammatory process with the presence of fibroblastic proliferation of organized collagen fibers (Score 2) (Figure 7A-B). After day 7 , the microscopic alterations were characterized by the absence

FIGURE 5 - Area with trauma- induced ulcers in the cheek mucosa of rats. (A) Relation between the area of the ulcer and time was analyzed by ANOVA test with Tendency post-test $\left(\mathrm{R}^{2}=0.87 ; \mathrm{p}<0.0001\right)$. (B) Relation of the percentage of ulcer contraction and time $(\mathrm{p}<0.0001)$.

\section{Histopathological analysis}

Microscopic analysis of the sections in the cheek mucosa of rats on the first and second days after the induction of the trauma revealed the presence of an acute inflammatory process constituted by extended part of ulceration associated with dilated vessel, hemorrhagic areas and mixed inflammatory infiltrate with the predominance of neutrophils (score 4) (Figure 6A-B). On the third and fourth days after the injury, the histological profile was composed by a lymphoplasmocytic inflammatory infiltrate, proliferation of fibroblasts and some neoformed capillaries (score 3) (Figure 6C). 


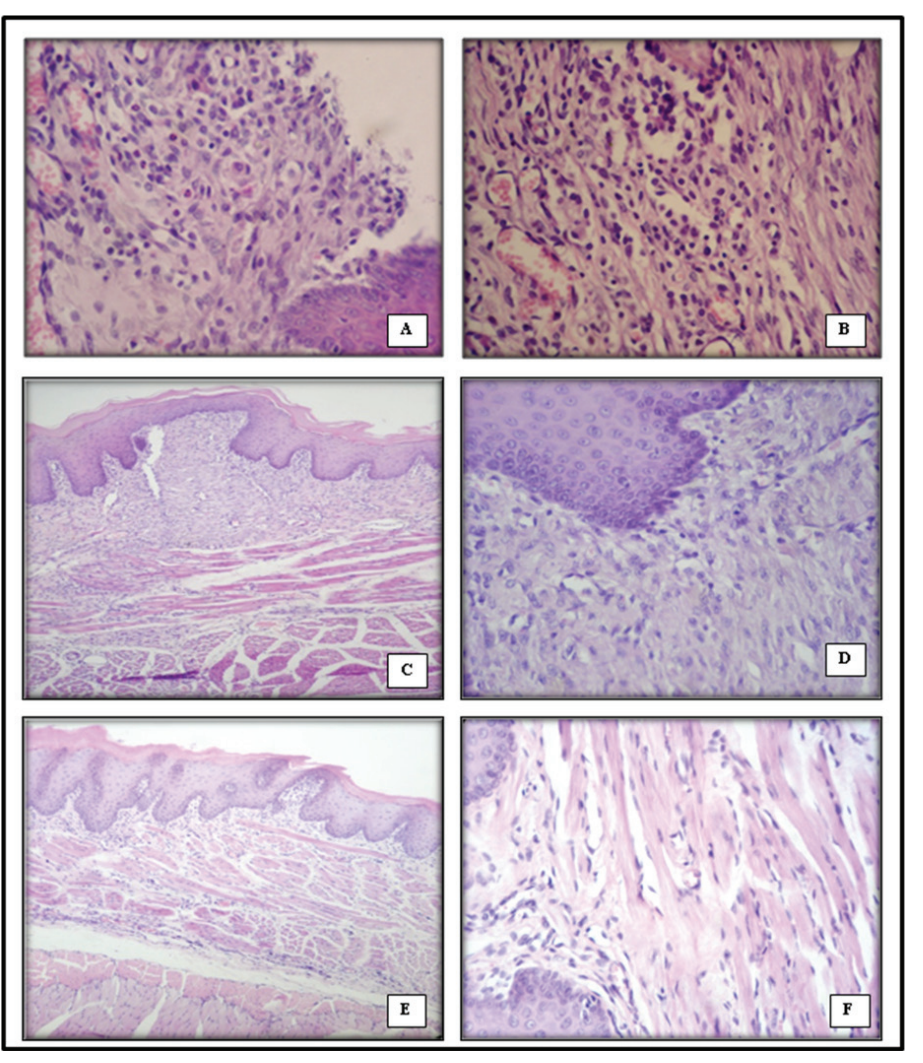

FIGURE 7 - Photomicrograph of histological sections from the days 5-10 of evolution (A). Persistence of the ulcer (arrow) and (B) presence of mononuclear cells and dilated vessels on day 5 after ulceration (HE, 400X). (C) Absence of ulcer and fibrosis (HE, 200X). (D) Presence of discreet chronic inflammatory infiltrate (HE, 400X). (E) Absence of ulcer and remodeling of the collagen fibers (HE, 200X). (F) Remodeling of collagen fibers (HE, 400X).

After the histological analysis and evaluation, scores were tabulated for regression, and statistical significance was observed among the groups between days 1 and 9, 1 and 10, 2 and 9, 2 and 10, 3 and 9, and 3 and 10 ( $\mathrm{p}<0.01$ ) (Figure 8). We observed that groups at the $1 \mathrm{st}, 2 \mathrm{nd}$ and 3 rd days displayed similar results, but the scores decreased after day 4 .

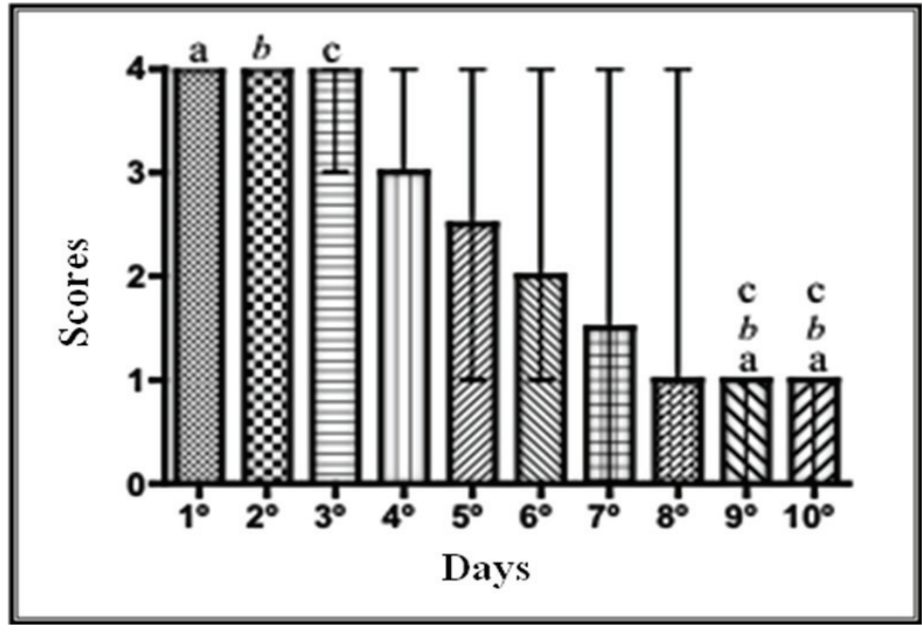

FIGURE 8 - Median and amplitude of the histopathological scores of the animals subjected to traumatic ulceration induction in the cheek mucosa. Comparisons were made by non-parametric Kruskal-Wallis test followed by Dunn post-test $(p<0.01)$. Statistically significant differences were observed among groups at days 1 and 9 (a), 1 and 10 (a), 2 and 9 (b), 2 and 10 (b), 3 and 9 (c), and 3 and 10 (c).

\section{Discussion}

The use of animal models has allowed for analysis of some aspects of the oral cavity and other associated structures that would not be easily studied in humans.

In the studies involving the oral mucosa, rats are commonly used because they present some advantages in relation to other animals. Among these advantages are: the low cost, the easy manipulation, maintenance in controlled environmental and sanitary conditions including special diets ${ }^{16}$. Another advantage is the similarity between the oral mucosa of rats and humans, which is basically by made up of epithelial tissues on the surface and subjacent connective tissue, called basal lamina which offers support and nutrition to the epithelium ${ }^{13}$.

Traumatic ulcers are the most common inflammatory ulcerative conditions in the oral cavity, and the cheek mucosa is the most traumatized site. Such traumas are caused by poorly adapted prosthesis or occlusal disharmony, tooth crowns or fractured restorations and even by accidental bites while chewing or habits ${ }^{3-5}$. Although it is the focus of intense research, there is no consensus in the literature about a definite therapeutic protocol, and many times inadequate treatments, such as the use of synthetic substances, phytotherapy and herbs are used by some of the population. Therefore, there is a need to establish experimental models able to test such substances as well as the ones available on the pharmaceutical market. 
In the present study, the evolution phases of the macroscopic aspect of the ulcers followed the same patterns observed by Marcondes ${ }^{13}$ in 2002 who evaluated the tissue repair of surgical lesions in the oral mucosa of rats using a 2-mm "punch" for dermatological biopsy. Their study revealed that 20 days after of the surgical procedure, there was a complete repair of the lesion in all the animals. These data corroborate our clinical findings in which the cheek mucosa of all the animals were completely cicatrized 10 days after beginning the experiment.

In regard to body weight, there was a decrease in the body mass in all groups during the first five days. This initial loss was caused by the process of ulcer induction in the mucosa, impairing feeding. As the cicatrization proceeded, the feeding process was reestablished, and consequently weight gain, which explains the increase in body mass after the fifth day. This result was confirmed after the analysis of the dose-response curve once the ulcerated area was already $50 \%$ contracted in this period. These results are similar to the findings by Alves et al. ${ }^{18}$ who inoculated Walker Carcinoma 256 tumor cells into open alveoli of the first and second inferior molars after extraction. The animals lost weight in the first two days of the experiment but gained weight after the fifth day. This demonstrates that open injuries in the oral cavity impair the feeding process, causing the animal to lose weight.

Regarding the analysis of the ulcerative area, no significant decrease was observed during the first two days. However, after the third day, the area of the injury started to recede at a constant rate and progressively declined until the final day. These data confirm the study by Cross et al. ${ }^{15}$ where a model for the evaluation of the cicatrization dynamics in injuries made in the dorsal area of rats and guinea pigs was established. According to the authors, the correlation coefficient (R), which was similar to what was found in our graph on the reduction of the ulcerated area (Figure 5A), approximates 1, suggesting a high reproducibility of the studied results.

Through microscopic evaluation, after day 7, a positive significant effect of cicatrization on reepithelization (the time for epithelial reconstruction) was observed. This was similar to the findings by Amorim et al. ${ }^{14}$ who evaluated the cicatrization process of 1-cm incisions in rat bladders. During the first two days after induction of the ulcer, a slight decrease in tissue repair was observed due to the extended amount of ulceration and the predominance of polymorphonuclear neutrophils. However, Okabe and Amagase ${ }^{20}$ reported that after the first three post-surgical days, the rate of repair recovers once the acute inflammatory process reaches its peak and other activities start to modify the environment, which leads to tissue repair. In this phase, a change in the histological content can be observed, including the presence of a mononuclear cell infiltrate, mainly lymphocytes and macrophages. These macrophages increase their metabolism when activated and begin to release products that act as intermediates of inflammatory response events and growth factors, promoting the repair of tissues damaged during the inflammatory process. However, on days 7 and 8 , one animal of each group still displayed persistent acute inflammation. This may be due to a secondary infection by bacteria from the oral microbiota during surgical injury, which slows down the repair process of the cheek mucosa due to maintenance of a local inflammatory reaction.

To complete the repair process, abundant granulation tissue, characteristic of chronic inflammation, grows form the border in a centripetal pattern at the thickness of the surrounding skin/mucosa, which reduces the size of the injury. This is performed by activated fibroblasts, here myofibroblasts, which have similar properties to the smooth contractible muscle cells that allow for the necessary contraction and tension to repair the damage ${ }^{17}$.

The cicatrization process, similar to what happens in any inflammatory process, consists of steps with a sequence of alterations that can be observed throughout the period of tissue repair. The role of growth factors in the migration, proliferation and differentiation of epithelial cells, in the formation of connective tissue and growth of new vessel is of great importance.

Thus, the proposed model is similar to human traumatic ulcers regarding both the pathological characteristics and the cicatrization mechanism. These ulcerations represent inflammatory lesions that are extremely symptomatic that also impair feeding and the patient's quality of life.

\section{Conclusions}

The cicatrization process of the mucosa in rats is similar to cicatrization in human beings. The proposed cheek mucosa ulcer model in rats can be considered an efficient process that offers reliable, reproducibility, and a low cost. The permanence time of the ulcer allows for testing of alternative therapies in vivo that have so far only been used empirically.

\section{References}

1. Razmus TF. Tongue ulcerated by trauma: report of a case. J Am Dent Assoc. 1992;123(5):82-6.

2. Pérez MA, Raimondi AR, Itoiz ME. An experimental model to demonstrate the carcinogenic action of oral chronic traumatic ulcer. J Oral Pathol Med. 2005;34:17-22.

3. Compilato D, Cirillo N, Termine N, Kerr AR, Paderni C, Ciavarella D, Campisi G. Long-standing oral ulcers: proposal for a new "S-C-D 
classification system”. J Oral Pathol Med. 2009;38:241-53.

4. Akintoye SO, Greenberg MS. Recurrent aphthous stomatitis. Dent Clin N Am. 2005;49:31-47.

5. Murray B, McGuinness N, Biagioni P, Hyland P, Lamey PJ. A comparative study of the efficacy of AphthealTM in the management of recurrent minor aphthous ulceration. J Oral Pathol Med. 2005;34:413-9.

6. Woo SB, Sonis ST. Recurrent aphthous ulcers: a review of diagnosis and treatment. Dent Clin N Am. 1996;127:1202-13.

7. Fraiha PM, Bittencourt PG, Celestiano LR. Estomatite aftosa recorrente: Revisão bibliográfica. Rev Bras Otorrinolaringol. 2002;68(4):571-8.

8. Coelho K, Araújo CSA. Tratamento de ulcerações aftosas recorrentes: uma revisão bibliográfica. Publ UEPG Ci Biol Saúde. Ponta Grossa 2005;11(3/4):39-45.

9. Lima AAS, Grégio AMT, Tanaka O, Machado MAN, França BHS. Tratamento das ulcerações traumáticas bucais causadas por aparelhos ortodônticos. R Dental Press Ortodon Ortop Facial. 2005;10(5):30-6.

10. Neville BW, Damm DD, Allen CM, Bouquot JE. Patologia Oral e Maxilo Facial. 3ed. Rio de Janeiro: Editora Guanabara Koogan; 2009.

11. Menezes FF, Coelho MCOC, Leão AMAC, Pereira Junior JR. Avaliação clínica e aspectos histopatológicos de feridas cutâneas de cães tratadas com curativo temporário de pele. PUBVET. 2008; 2(4): Jan4. Disponível em URL: <http://www.pubvet.com.br/texto. php?id=128>

12. Cho SA, Park JH, Seok SH, Junh JH, Kim SJ, Ji HJ, Choo YS, Park J.H. Effect of granulocyte macrophage-colony stimulating factor
(GM-CSF) on 5-FU-induced ulcerative mucositis in hamster buccal pouches. Exp Toxicol Pathol. 2006;57(4):321-8.

13. Marcondes CA. O reparo tecidual da mucosa bucal de ratos submetidos ao alcoolismo crônico experimental [Dissertação de Mestrado]. FOP, UNICAMP, Piracicaba; 2002.

14. Amorim E, Matias JEF, Coelho JCU, Campos ACL, Stahlke Jr HJ, Timi JRR, Rocha LCA, Moreira ATR, Rispoli DZ, Ferreira LM. Efeito do uso tópico do extrato aquoso de Orbignya phalerata (babaçu) na cicatrização de feridas cutâneas - estudo controlado em ratos. Acta Cir Bras. 2006;21(Suppl 2):67-76.

15. Cross SE, Naylor IL, Colemant RA, Teo TC. An experimental model to investigate the dynamics of wound contraction. Br J Plast Surg. 1995;48:189-97.

16. Sullivan TP, Eaglstein WH, Davis SC, Mertz P. The pig as a model for human wound healing. Wound Rep Reg. 2001;9:66-76.

17. O'leary R, Wood EJ, Guillou PJ. Pathological Scarring: Strategic Interventions. Eur J Surg. 2002;168:523-34.

18. Alves APNN, Guedes RC, Lotufo LVC, Moraes MEA, Pessoa LO, Ferreira FVA, Moraes MO. Modelo experimental de tumor na cavidade oral de ratos com carcinoma de Walker 256. Acta Cir Bras. 2004;19(4):406-14. Disponível em URL: http://www.scielo.br/acb.

19. Tarnawski AS. Cellular and molecular mechanisms of gastrointestinal ulcer healing. Dig Dis Sci. 2005;50:S24-33.

20. Okabe S, Amagase K. Anoverviewof acetic acid ulcer models - the history and state of the art of peptic ulcer research. Biol Pharm Bull. 2005;28(8):1321-41.

\section{Correspondence:}

Ana Paula Negreiros Nunes Alves Av. Rui Barbosa, 880/1901

60115-220 Fortaleza - CE Brasil

Phone: (55 85)3366-8421

ananune@terra.com.br
Conflict of interest: none

Financial source: FUNCAP

Received: November 10, 2010

Review: January 12, 2011

Accepted: February 14, 2011 